\title{
2. MOTILITY IN SPORT-ARTISTIC ACTIVITIES - A SOCIAL PHENOMENON
}

Ana-Cristina Leșe ${ }^{170}$

\begin{abstract}
The history of Physical Education reports us that the physical exercises have emerged and have been perfected in accordance with the social order, evolving in direct relation with it. During this paper we will define the phenomenon of Physical education and sport as a discipline of academic education, starting from the general notions to the particular ones in the general physical training of the student actor. In this paper we try to highlight some similarities between the preparation of the actor and the preparation of the athlete for professional performance. We will present the theoretical framework with well-defined and accepted notions in both sports and theater. We will subsequently present the particular framework in which the theoretical principles in the sports field are taken over by the university theater programme and put into practice for the general preparation of the future actor. The article closes with the selection of some basic conclusions and recommendations appropriate to the topic under discussion
\end{abstract}

Key words: Actor, general physical training, sportsman, physical exercises

\section{General framework}

The social phenomenon includes a suite of social facts or, following the formulation of Emile Durkheim, a set of social facts, such as legal and moral norms, habit, language, behavioral rules, religious precepts and so on. The distinction between social phenomenon and social fact in the space in which sociology manifests is small, sociologists frequently operating with the two terms, as historians do. Physical education and Sport, under their fundamental aspect, as human activities endowed with a social function and contributing to the formation and development of the personality, can have a decisive impact on the profession of the artists. This is because the organized physical exercise contributes to the enrichment of the artist student's patrimony: first, helps at the development of creativity by stimulating intelligence and sensitivity, then, it contributes to combating the deficiencies of posture that may appear in these professions and, last but not least, it contributes to the social integration in different groups formed spontaneously.

The discipline of Physical Education and Sport must be understood starting with its history, terminology, objectives, influences and continuing with specific characteristics always adapted to the development of this field, all being within the structure of this SOCIAL PHENOMEN process. In the field of Physical Education and Sport there are objectives with physiological functions, others with instructive-educational functions and last but not least, objectives with social

\footnotetext{
${ }^{170}$ Associate Professor PhD., "George Enescu" National University of Arts from Iaşi, Romania, email: analese2000@yahoo.com
} 
functions. If we combine the functions: educational, relaxation, entertainment, hygiene, self-reliance, we reach the interpersonal relationships that are so important in the development of youth.

The physical sporting activities in the artistic academic education from Iasi are carried out in different forms: dance, fence, Tai Chi, Acrobatics, Scenic movement at the Theater Faculty; sports games, development of psycho-motor qualities at the Faculty of Visual Arts and Design and at the Faculty of Music. In these conditions of existence of a wide range of physical exercises, we must offer some of the theoretical, basic notions, which will lead to the awareness of the movements. Of course I have published other studies with introductory notions in the field of Physical Education and Sport, but we can never say that everything has been written. "The sociology of Physical Education and Sports (EFS) is focused on the character and content of the activity, the person's attitude towards physical exercises, the organization and conditions of the sport, the behavior of the sportsman and the spectator, the values, motivations and satisfactions offered by the practice of sport" ${ }^{171}$. In sociology, a social phenomenon defines a relationship, a process, a way of organizing.

\section{Particular framework - incursions in the motility through sport activities in the theater field}

"The history of Physical Education reports us that the physical exercises have emerged and have been perfected in accordance with the social order, evolving in direct relation with it. Over time there have been ascents in the development of physical exercises but also stagnations or even regressions being influenced by the politics and economy of the society. We acknowledge, however, that the evolution in time of sports facilities, outdoor or indoor sports facilities, materials, working technique is very pronounced. This evolution is noted by the sports performances obtained today and by the superior quality of all the components that support Physical Education and Sport (from sports bases, equipment, techniques and to the principles of training and practicing physical exercises) $" 172$.

Some brief references to the origin of the physical exercise and how it has been taken over by the different fields that use it in carrying out the specific activity are necessary here. Physical exercise has been present as a biological and social necessity in human life since ever; it appeared and gradually developed in the process of work and survival, outlining, over time, some forms of practice, such as: running, jumping, climbing, fighting, swimming and rowing, games, dancing, etc. Some of these forms of exercise can be found today in the training of the actor (stage fights, games and dance). Other explanations in the theory and practice of physical education and sport come to support the importance of physical exercise: "Physical exercise is the basic means that constitute the core of

Oana Rusu, Sociologia Educației fizice și Sportului, Demiurg Publishing House, Iași, 2008, pp.11-12

172 See Carmen Voiculescu, Istoria Educaţiei fizice şi sportului, Constanţa, Ovidius University Press, 2002, p. 18 
the system of physical education means. Without it, the respective motor activity cannot exist ${ }^{173}$ ". And „Physical education is the activity deliberately built and carried out mainly for the improvement of the physical development and the motor capacity of the human being, according to the particularities of age, sex and the specificity of the profession ${ }^{174 "}$.

Physical exercise, considered the main means of performing physical education (body education) is also the basic means (instrument) of sport. But sport also contributes to the complete physical (bodily) education. We will often encounter the formulations of physical education and bodily education. They express, in fact, the same thing, but sometimes we associate them, in order to extend a bridge to the discipline The Training of the bodily expression, thus making it possible to approach the two disciplines. Of all the definitions we encounter, we note the one according to which: Sport is a summing of physical exercises and games, practiced methodically and systematically in order to strengthen health, to develop physical and mental capacities (the will, mainly) and to obtain performances. Compared to physical education, the sport includes, in the process of preparation (sports training), higher intensity structures, more complex and with daily use or three - four times a week.

In connection with the discipline of Physical Education in the academic theater program, we affirm that in the history of the theater, the idea that the moment of the birth of the western theater is related to the representations from Ancient Greece, meant to celebrate the god Dionysos, is unanimously accepted. Researches in the History of Physical Education and Sport attest that Sport has the same origin, outlined in the organization and institutionalization of the Olympic Games, with Olimpia representing the sacred arena, the focal point and symbol of Greek life. Looking back, we can see that, where the representation and the ceremonial are present, the physical exercise and the movement, sports competition or scenic game are used, in forms that differ from the theater performance. Sport, physical education and theater are brought together through forms and practices that succeed, each maintaining its autonomy.

The ideal of Physical Education in the formation of the actor tends to place the spirit with the force in an interdependence relation, because the spirit needs a language to manifest itself, and the movements focus on the psychic concepts. The issue of Physical Education cannot but be of interest in the theatrical environment, as it is almost self-evident that Physical Education facilitates the preparation of other Movement disciplines in the actor's training program. Ensuring a higher quality of the actor and artist's training in general is generated by a higher development of all physical and mental competences.

When we speak of physical competences, we refer to psychic components, such as thinking, will, memory. Physical education must be seen as an authentic

\footnotetext{
${ }^{173}$ Gh. Cârstea, Educaţia fizică - Teoria şi bazele metodicii, Bucureşti, National Academy of Physical Education and Sport, 1997, p. 60

${ }^{174}$ Ibidem
} 
formative process, the purpose of which is given by the multitude of skills, abilities and attitudes, acquired by the acting students. This motility luggage, once formed, will have a modeling impact on the other disciplines of movement and, implicitly, on the game on the stage, on the artist's creativity. It is essential for the artist to know methods of learning the components of physical education (skills, abilities and motor attitudes), which will be fixed mentally and in physical expression, removing the wrong technical aspects in their execution (for example, in performing acrobatic elements).

Acquiring a special physical capacity requires a high degree of educability, which must be achieved in the form of continuous and complex training, both technically (clear, correct executions, with minimal effort) and artistic. The care of the artist for the health, vigor and youth of the body is the same as the care for the dental health, as the authors explicitly state in the article THE CLINICAL METHODS TO MEASURE TOOTH WEAR. ${ }^{175}$

The motility capacity means ,the set of natural and acquired motor possibilities through which various efforts can be made in structure and dosage". In the process of educating and training of performance athlete, of the studentactor and the young actor, this capacity will be required through a conscious and active participation, creating a communication through movement and by its force of expression, in order to achieve the creative act - the theatrical performance. In the information networks (ICT) we find many articles on Physical Education in Romania, very well documented. From such sources we were also inspired to make a brief presentation of the moment of the introduction of Physical Education in the Romanian pre-university education.

Ancient Greece has stood out in the whole history of human education, by perceiving ,the human being as a complex, a combination of physical and spiritual properties, always perfectable and directed towards the ideal. It is not by accident that sport and culture have identical roots " ${ }^{176}$. In the creative process that is culture, physical exercise, through its effects stimulates, balances, and ennobles the human being, the notion of physical culture being fully justified as a syntagm that expresses the process of body cultivation.

\section{The importance of general physical training for acting students}

For the development of the complete actor, the study of the scenic movement (the specific corporal education) occupies an important place, contributing to the harmonious, artistic development of his own bodily activity, of the gesture and of the mimicry. The interpretation of a role is largely based on the quality of the scenic movement and the modern actor must be aware of the importance of physical actions in the performance of the role. ${ }^{177}$.

\footnotetext{
${ }^{175}$ AAS Obeyah, Ibrahim-Z-Al-Shami, AO Armencia, THE CLINICAL METHODS TO MEASURE TOOTH WEAR ROMANIAN JOURNAL OF ORAL REHABILITATION 9 (2), 100-104

${ }^{176}$ Vezi Rene Maheu, apud Antonie Mihail, Antrenamentul expresiei corporale. Course, Craiova, Universitaria Publishing House, 2005, p. 7

${ }^{177}$ A Ciobutaru, A Armencia, M Ursache, The influences of chemical composition upon the hardness and atability
} 
The actor's motility actions are numerous and varied, through their whole, manifesting his active attitude towards the external world and its conditions. General physical training is the fundamental part of physical training. It pursues the development of basic physical qualities such as strength, speed, endurance, skill and is necessary for both the athlete and the actor. The content of the general physical training is characterized by the fact that it assures the learning of the most important forms of motor activity, necessary for the actor's training, such as: walking, running, crawling, dragging, climbing, crossing over obstacles, etc.

"Sport can express all feelings, all human emotions, just as culture and cultural spectacle - especially dance and theater, the most complete arts - express feelings and emotions in the actor and, through sympathy, in the spectator. Sport, like theater, literature or art, is a creator of myths. There is a sports mythology. Sport has its legends, its heroes and, whatever its mode of expression, it demonstrates the creative power and reveals the close connection between the complete arts and sports ${ }^{178 . "}$

\section{Conclusions}

The motility sports activities, as a social phenomenon within the general preparation of the future actor, fulfil objectives similar to those of the sportsman's preparation for performance. We list the following:

- development of basic motility qualities, emphasis on coordinative capacities;

- the acquisition of a rich fund of general motility;

- increased cardio-respiratory capacity;

- ensuring the general recovery, especially the mental one (in order to resume the spectacle on the same day or prepare another).

\section{Recommendations}

Physical education and sport largely supports the actor's complex training. - The teachers of the Theater Faculty have the necessary training to work different acrobatic exercises but the contribution of a physical education teacher has proved very helpful.

- In order to detail some acrobatic elements and to prepare the students to be able to perform certain motility actions, the hours of physical education can solve these tasks under the guidance of the teacher.

- Practicing physical exercises in different forms and after finishing school courses (high school and university).

- The actor does not only need general physical training but also needs to go into detail in the principles and methodology of physical education and sports training.

\section{References}

\section{AAS Obeyah, Ibrahim-Z-Al-Shami, AO Armencia, THE CLINICAL}


METHODS TO MEASURE TOOTH WEAR, 2017,_ROMANIAN JOURNAL OF ORAL REHABILITATION 9 (2), 100-104

2. A Ciobutaru, A Armencia, M Ursache, The influences of chemical composition upon the hardness and atability of prothetic restoration materials, 2011, Romanian Journal of Oral Rehabilitation 3 (1), 120

3. Cârstea, Gh., 1997, Educaţia fizică - Teoria şi bazele metodicii, National Academy of Physical Education and Sport, Bucureşti, p. 60

4. Leșe, Ana-Cristina, 2011, Actorul și sportivul pe căi comune, Artes Publishing House, Iași , p. 68

5. Maheu, Rene, 2005, Antrenamentul expresiei corporale. Course, Universitaria Publishing House, Craiova, p. 7

6. Rusu, Oana, 2008, Sociologia Educației fizice și Sportului, Demiurg Publishing House, Iași, pp.11-12

7. Voiculescu, Carmen, 2002, Istoria Educaţiei fizice şi sportului, Ovidius University Press, Constanţa,p. 18

8. UNIVERSITATEA ECOLOGICA BUCURESTI, Faculty of Physical Education and Sport, Sport - a social phenomenon of universal character, http://www.creeaza.com/familie/sport/SPORT-FENOMEN-SOCIAL-CU-

CARACT476.php, 20 oct. 2019 